\title{
Regional factors enabling manufacturing reshoring strategies: A case study perspective
}

\author{
Diletta Pegoraro ${ }^{1,2}$, \\ Lisa De Propris ${ }^{1}$ and \\ Agnieszka Chidlow ${ }^{1}$
}

\footnotetext{
${ }^{1}$ Birmingham Business School, University of Birmingham, University House, 116 Edgbaston Park Rd, Birmingham B15 2TY, UK; ${ }^{2}$ Economics and Management Department, University of Trento, Via Vigilio Inama, 5, 38122 Trento, Italy

Correspondence:

D Pegoraro, Birmingham Business School, University of Birmingham, University House, 116 Edgbaston Park Rd, Birmingham B15 2TY, UK e-mail: d.pegoraro@pgr.bham.ac.uk
}

\begin{abstract}
Firms' reshoring strategies have recently sparked academic and policy interest due to their contribution to rebalancing advanced economies. In line with the ongoing debate and by examining the journey of a company based in the West Midlands region of the UK, this work illustrates the adoption of a manufacturing reshoring strategy in response to a changing competitive environment. Further, by utilizing a mixture of primary and secondary data, this work not only shows how regional dynamics are pivotal for attracting manufacturing reshoring but also how regional characteristics can change the narrative on reshoring from a national to a regional focus. By doing so, this work demonstrates how regional implementation of industrial policies can facilitate a multiplier effect in the value of the region by increasing the attractiveness of hosting a manufacturing reshoring strategy.

Journal of International Business Policy (2022) 5, I 12-133.

https://doi.org/ | 0.1057/s422 I 4-02 I -00 I I 2-x
\end{abstract}

Keywords: reshoring; manufacturing; region; industrial policy; case theoretic approaches; global value chain

\section{INTRODUCTION}

The global economic landscape in which firms operate has been changing radically over the past 10 years (UNCTAD, 2019; 2020). By becoming a significant global player and a node in global production, China has shifted trade patterns from North-to-South to South-to-North and South-to-South (Baldwin \& Venables, 2013; Hamnett, 2018). Emerging economies are also assuming a leading role in terms of foreign investment (Guillén \& García-Canal, 2009), as well as becoming lucrative consumer markets. The global financial crisis of 2008 was a turning point, as it unveiled the socio-economic cost of the de-industrialization that had taken place in Europe and the USA since the 1980s (Bailey \& De Propris, 2020). Economic recovery was in part endorsed with a more promanufacturing narrative and more protectionist policies (UNCTAD, 2020). With this backdrop, firms have also started more recently to explore what implications new technologies linked to the Fourth Industrial Revolution might have, not only on the
Received: 31 August 2019

Revised: 18 March 2021

Accepted: 25 March 2021

Online publication date: 17 May 2021 
economic and social aspects of life, changing human behaviors, and their strategies (UNCTAD, 2017), but also on the value chain (Finley, 2019; Strange \& Zucchella, 2017).

A renewed interest in manufacturing by advanced economies seems to be mainly driven by two transformative trends. On the one hand, evidence suggests firms are giving up global sourcing for more local and pancontinental value chains with multiple nodes across continents and fewer supply tiers, to leverage market closeness (Chen \& Lombaerde, 2019; De Propris \& Pegoraro, 2019; Gereffi, 2018). On the other hand, the pervasive adoption of new labor-substituting technologies is allowing firms to restructure their global value chains (GVCs) by swapping overseas laborintensive operations for home capital-intensive ones (Ancarani \& Di Mauro, 2018; Ancarani, Di Mauro \& Mascali, 2019; Baldwin, 2019; Dachs, Kinkel \& Jäger, 2019; Strange \& Zucchella, 2017).

Such trends arguably require not only vision, leadership, and commitment by national governments, but also the active engagement of local governments in the implementation of policies that inevitably have local and regional implications. In particular, such renewed interest in manufacturing has also galvanized national policymakers, which have put in place manufacturingfriendly initiatives and instruments in order to recreate a dense industrial base and related competencies, as well as to technologically upgrade the industrial base as a necessary condition for the long-term prosperity of their countries (De Backer, Menon, Desnoyers-James \& Moussiegt, 2016). However, as industries are not evenly spread within countries (Boschma, 2015), national-level policies tend to have different impacts across regions, depending on their openness and connectivity to the world (Resmini, 2019), their degree of embeddedness in regional innovation systems (Parilli, 2019; Pietrobelli \& Rebelloti, 2011), as well as on their comparative advantages and competitiveness (Neilson, Pritchard \& Yeung, 2017). To address such regional heterogeneity, regional policy-makers are therefore tasked with designing specific initiatives that match the needs of local industries and firms in moving up their upgrading trajectory (Humphrey \& Schmits, 2002).

In this paper, we focus on policies that relate to incentivizing firms to adopt reshoring strategies. According to the literature, reshoring can be defined as the strategy firms adopt when they decide to move all or part of their production from a host country to the home country, either by closing operations abroad to open them at home or by switching from international to domestic suppliers (Fratocchi, Di Mauro, Barbieri, Nassimbeni \& Zanoni, 2014). Therefore, we embrace a definition of reshoring as a strategy that a firm adopts when it decides to bring its production back from a host country to the home country (Ellram, Tate \& Petersen, 2013).

Bearing in mind such an understanding, this paper introduces the concept of locally implemented reshoring policy as a subset of manufacturingfriendly policies aimed at thickening a country's industrial base at the regional level. In doing so, firstly, this work sees reshoring as a multidisciplinary concept that should be examined through the joint lenses of the international business and economic geography fields. This is because although it is integral to the field of international business, reshoring can only be fully understood if we also consider the specific characteristics of the home country's regional locations as well as the implication that local settings have on the organization of firms' value chains as theorized within the economic geography field. Such a combined conceptualization of reshoring allows us to better analyze what shapes a reshoring policy directed at influencing firms' location decision choices in order to re-populate or upgrade a country's industrial base at the regional level. Secondly, based on the above, the paper aims to investigate regional interactions amongst policy, technological, local ecosystem, and local supply chain issues when companies decide to reshore manufacturing activities. This is because, under such a perspective, companies' production decisions could demonstrate how policies implemented by regional authorities may act as enabling factors for their reshoring strategies.

In doing so, this work focuses on a single case study of a company located in the West Midlands, a region of the United Kingdom (UK). The regional scale adopted here is in line with the Nomenclature of Territorial Units for Statistics (NUTS) level 2 (Eurostat, 2018) and offers an excellent opportunity to discuss the importance of firms' manufacturing strategies in conjunction with the role of reshoring policies in pursuit of regional development. Moreover, it furthers our understanding of how a firm's fundamental objective to change its global exposure and to redefine its competitive advantage via reshoring can trigger a process of upgrading the value creation of its local operations thanks to the 
adoption of Industry 4.0 technologies. Overall, it highlights the importance of a regional industrial policy implemented by local institutions that can support firms' decisions to either invest in the region or favor closer suppliers with a view of capturing more value from the GVCs (Bailey, Corradini \& De Propris, 2018).

The case study analyzed in this paper is based on qualitative primary data collected via in-depth interviews with a chief executive officer (CEO) and policy-makers between December 2018 and August 2019. These primary data were complemented by other secondary sources in order to obtain a holistic understanding of manufacturing reshoring strategies in the West Midlands.

The novelties of this paper are threefold. Firstly, this work contributes to the emerging dialogue between the fields of international business and economic geography on the role of place in firms' location decisions (Boschma, 2015; Cantwell, 2009; Chidlow, Salciuviene \& Young, 2009; Chidlow, Holmström-Lind, Holm \& Tallman, 2015; Mudambi, Li, Ma, Makino, Qian \& Boschma, 2018), by illustrating that national policies implemented at the regional level can play important roles in connecting firms to a specific location so that space-aware choices can be made. Secondly, drawing on the GVC framework, this work focuses on a bottom-up approach and links reshoring to upgrading strategies that allow "countries, regions, and other economic stakeholders to maintain and/ or improve their positions in the global economy" (Gereffi, 2011: 39-40). Finally, by framing reshoring as a strategic decision that a firm takes considering the regional-level characteristics of the home economy, this work looks at firms' location decisions in light of their local ecosystems (Humphrey \& Schmits, 2002; Iammarino \& McCann, 2013). Overall, the main finding of the paper is that a locally implemented reshoring policy can be successful in strengthening a country's industrial base by improving firms' value creation, which in turn can foster a region's technological upgrading and strengthen its position in its GVC.

The remainder of the paper is structured as follows: Introduction section presents the relevant literature and the conceptual framing that underpins this work. Literature review section explains the data collection and methodology. Research methodology section presents and discusses the case study situated in the West Midlands. Some policy implications and concluding remarks end the paper in Case study: Overview and analysis section.

\section{LITERATURE REVIEW}

\section{De-globalization and Reconfiguration of Value Chains}

The global financial crisis of 2008 showed that countries' interconnectedness in terms of trade, production, and finance could be a source of instability and peril; this gave scholars different insights into the previous uncompromised enthusiasm towards globalization (van Bergeijk, 2018). Decades of de-industrialization caused by the shift of manufacturing operations by multinational companies (MNCs) from high- to lower-wage countries were exposed more visibly and tangibly by the financial crisis, especially in the de-industrialized regions of advanced economies where the social cost of globalization was the greatest. Such economically displaced and impoverished communities were also more adversely hit by the austerity policies that followed, justified by national governments to balance public finances and secure economic and political recovery (Mudambi, 2018).

In this context, we have seen national governments increasingly engaged with industrial GVC policies at the national level aimed at supporting local economies move along and up an upgrading trajectory to build a sustainable competitive advantage (De Propris \& Pegoraro, 2019; Gereffi \& Sturgeon, 2013; McKinsey, 2019; UNCTAD, 2018, 2020). We are now also witnessing a reorganization of GVCs away from having truly global operations, as firms' strategies seem to be increasingly shaped by national and regional forces. This shift has been led in part by policies that have encouraged shorter and closer value chains (De Marchi, Di Maria \& Gereffi, 2017), with locally implemented reshoring policies intervening directly in local industrial clusters and local supply chains.

Further, recent studies confirm that MNCs have started shortening their supply chains with a greater reliance on local suppliers around major hubs whose expertise and technological readiness have become more important than costs (Nujen, Mwesiumo, Solli-Sæther, Slyngstad \& Halse, 2019; Sirilertsuwan, Hjelmgren \& Ekwall, 2019). To drive this manufacturing renaissance, national-level policies and locally tailored instruments have openly supported the repopulation of the manufacturing 
industries, enabled by the formation or re-creation of local supply chains that have remained, nevertheless, globally connected through the MNCs (van Assche, 2018). Even though the true impact of deglobalization is still uncertain, manufacturing reshoring strategies are being seen as part of this resurgence due to their contribution to the reorganization of GVCs by fostering a de-coupling of MNCs from developing countries (Kandil, Battaïa \& Hammami, 2020). What is more, the recent Covid19 pandemic will certainly have an impact on how firms' strategies centered around the configuration of their GVC location choices are being made including reshoring strategies - both by single firms and at the supply chain network level. This might be because approaches to reshoring might differ depending on the market segment a firm operates in (Barbieri, Boffelli, Elia, Fratocchi, Kalchschmidt \& Samson, 2020), switching costs or "the evolving geopolitical context and rising protectionist sentiments worldwide" (Strange, 2020: 464).

\section{Overview of the Determinants of Manufacturing Reshoring}

As a concept, reshoring originated from the supply chain management discipline, which largely focused on examining the push and pull factors when explaining the phenomenon (Canham \& Hamilton, 2013; Kinkel \& Maloca, 2009; Tate, Ellram, Schoenherr \& Petersen, 2014). According to that literature, push factors are related to the local conditions in the host economy that negatively impact the attractiveness of foreign operations in the host country due to, for example, the loss of production efficiency, the loss of flexibility, long lead and delivery times, and disruptions and frictions in the entire supply chain (Gadde \& Jonsson, 2019; Kinkel, 2014; Moradlou, Backhouse \& Ranganathan, 2017; Moretto, Patrucco \& Harland, 2019). By contrast, pull factors have the opposite effect, albeit with the same outcome. Pull factors consider the positive impact of the home country's features on firms' location choices, for example, enhancing firms' control and resilience over their supply chains, possibilities to collaborate with local suppliers, increased efficiency in the home country's production operations driven by technological investment (Ancarani \& Di Mauro, 2018; Lavissière, Mandják \& Fedi, 2016) and access to a base of domestic suppliers (Ashby, 2016; Foerstl, Kirchoff \& Bals, 2016; Fratocchi et al., 2016; Gray, Esenduran, Rungtusanatham \& Skowronski, 2017; Stentoft, Mikkelsen \& Jensen,
2016; Tate \& Bals, 2017; Wiesmann, Snoei, Hilletofth \& Eriksson, 2017).

In addition to the above literature, reshoring has more recently also been examined as a firm's location choice through the lens of international business (IB) studies (Ancarani, Di Mauro, Fratocchi, Orzes \& Sartor 2015; Arik, 2013; Delis, Driffield \& Temouri, 2019; Grappi, Romani \& Bagozzi, 2018; Strange \& Zucchella, 2017) as well as a place-aware strategic choice within the economic geography (EG) field (Bailey et al., 2018; Rasel, Abdulhak, Kalfadellis \& Heyden, 2019; Vanchan, Mulhall \& Bryson, 2018). This is due to a growing dialogue that has taken place between these disciplines revolving around the role of place and space for firms' operations (Beugelsdijk, McCann \& Mudambi, 2010; Beugelsdijk \& Mudambi, 2013; Markusen \& Venables, 2000; Mucchieli \& Puech, 2004). A mutual topic of interest for scholars in both disciplines is that firms' reshoring decisions relate to specific locations that present desirable local assets (e.g., competences or incentives) as well as being well connected at the international level (Crescenzi, Pietrobelli \& Rabellotti, 2014; Mudambi \& Puck, 2016).

A complex understanding of place and space, from the point of view of EG, is helpful in studying reshoring as it certainly allows consideration of the heterogeneity of specific location choices within a given home country when examining firms' manufacturing reshoring strategies, indicating the fact that such locally implemented reshoring policies should be part of a carefully planned decision equation (Baraldi, Ciabuschi, Lindahl \& Fratocchi, 2018). This is because the decision to bring back home either the entire or parts of a manufacturing activity present significant locational challenges. Indeed, Lampón \& González-Benito (2019) clearly point out that firms might choose not to reshore if the institutional context in which they operate is not conducive to creating a desirable local environment for manufacturing reshoring strategies. In line with the existing literature discussed above, below we focus our attention on describing the three types of pull factors relevant to our work.

\section{Manufacturing Reshoring and Political Pull Factors}

Several countries have adopted either ad hoc policies or established special task forces to revive manufacturing industries eroded by many years of offshoring practices. For example, in the USA, the Obama administration put in place strategic 
initiatives in order to encourage investments in the manufacturing industry and to support the "Made In the USA" label (The White House, 2012). In the document Blueprint for an America built to last (The White House, 2012: i), the US government promoted a production network called the Integrated Photonics Manufacturing Institute, as well as several schemes aimed at the adoption of green energy in the manufacturing sector (Barnow \& Hobbie, 2013; The White House, 2015). Such initiatives positively attracted the return of manufacturing firms (Moretto et al., 2019; Tate et al., 2014) as well as foreign investments into the USA in manufacturing industries (OECD, 2017). Creating manufacturing jobs was the slogan of Donald Trump's 2016 presidential campaign, who strongly supported the reshoring of manufacturing activities in the USA (Valli, 2018), but with an emphasis on protecting domestic producers with protectionist trade policies. So far, these policies have yet to deliver the employment boost that was expected, for two reasons: first, manufacturing value chains are still globally integrated and what can be located in the USA is limited; second, the advanced manufacturing productions that are reshored tend to be heavily automated and therefore create better quality but fewer jobs than expected (Eichengreen, 2020).

Similarly, the British government has launched several initiatives to support manufacturing firms. Amongst these was Reshore UK. Attention to reshoring was flagged in David Cameron's speech at the World Economic Forum, "I think there is a chance for Britain to become the Re-Shored Nation" (UK government, 2014: 67). In this policy context, reshoring policies in the UK tended to be coordinated through an ad hoc national initiative called Reshore UK, a scheme specifically designed to encourage firms to move back to the UK manufacturing production that was previously offshored or internationally outsourced. The scheme supported manufacturing firms in the process of planning their manufacturing reshoring strategy as well as assisting firms in finding suitable locations and relevant local suppliers (GOV.UK, 2014). It was launched in 2014 as a joint task force between UK Trade and Investment (UKTI) and the Manufacturing Advisory Service (MAS). The latter was the first contact point for small and medium-sized enterprises (SMEs) and MNCs seeking support in adopting a manufacturing reshoring strategy. The MAS provided advice on business strategies, innovative practices, efficiency-seeking solutions, and supply chain services (MAS, 2014). However, the UK's reshoring policies, including Reshore UK, lasted only 2 years, from 2014 to 2016, being prematurely aborted by the unexpected Brexit referendum result. Although the Conservative Party remained in power under Theresa May, its concerns and goals completely changed as the Brexit agenda dwarfed any previous policy priority. The Brexit negotiations with the EU would dominate the last part of the 2010s, creating an extremely confused and uncertain economic scenario, especially for firms and businesses (Gamble, 2018).

As the socio-economic costs of de-industrialization resulted from the firms' delocalization and offshoring strategies in the 1980s-1990s became more evident, in the early 2000s, the British government began launching local industrial policies aimed at supporting the manufacturing sector and its upgrading to the high value added end. To this end, a number of specific initiatives were launched aimed specifically at encouraging manufacturing firms to bring their foreign operations back to the UK: including the national 'Reshore UK' scheme and the 'Reshoring UK: UK Engineering Marketplace' online project. Both schemes create a platform to allow firms to find suppliers in the UK that better match their needs than foreign suppliers.

More broadly, over the last decade, various Conservative governments have endorsed industrial policies favoring manufacturing as sketched in Theresa May's Government White Paper on The New Industrial Strategy (UK government, 2017), which spelt out the government's steps to develop "A Britain fit for the future" (UK government, 2018). Here the policy ambition was to create ad hoc local industrial policies centered around specific challenges related to artificial intelligence, clean growth, future mobility, and the ageing society. It was notable, however, that while the topic of reshoring was not explicitly mentioned in the paper itself, a group of manufacturing research centers located across the UK and jointly called the High-Value Manufacturing Catapult (HVMC) was directly tasked to support reshoring strategies. The HVMC initiative was launched in autumn 2011 as part of the Innovate UK Research, Development and Innovation scheme lead by the UK's innovation agency and was aimed at supporting collaborations between firms and research organizations (i.e., universities) over $R \& D$ in order to encourage and support businesses in developing innovative products, processes, and services with future 
commercial potential. Specifically, the HVMC's "work is not only anchoring production in the UK, it is also helping to reshore manufacturing lost to other countries and winning the high-value inward investment projects that create jobs and local growth" (UK government, 2018: 82). In doing so, the Innovate UK scheme encouraged its beneficiaries to partner up with private industrial associations such as the Engineering Companies \& Manufacturing Association (GMTA) and British Measurement \& Testing Association (BMTA) to support reshoring activities throughout the country. As a result, the Reshoring UK: UK Engineering Marketplace online project was launched in 2016 to replace Reshore UK. Both aimed at highlighting the importance of a coordinated national industrial system that matched firms along the supply chain to rebuild delivered by supporting the regionally based manufacturing supply chains. This required promoting the strengthening of the skill base, firms' access to innovation, and technological capabilities. In this vein, in those years, the UK government launched funding schemes under the remit of the Department of Business, Energy \& Industrial Strategy, the so-called 'Sector Deals' (UK government, 2018) targeted at specific advanced manufacturing industries including aerospace, artificial intelligence, life sciences, and green transport. These are considered to be of strategic importance for boosting the productivity of the UK's economy (UK government, 2018). Although the strategic commitment is not only aimed at the manufacturing industry, the governmental engagement with multiple and diverse sectors indicates a willingness to support the development and growth of an inclusive and interconnected industrial base within the country. For example, in the automotive sector, the government has funded innovative ideas in advanced propulsion, a transition to ultra-low and zeroemission vehicles, and future mobility. An example is the Integrated Delivery Programme (IDP) series as part of the UK Research and Innovation (UKRI) aimed at "accelerating the transition to zero-emission vehicles' competition" (UK government, 2017: 1) where a company called OMNIA(CS) Ltd., was successfully awarded $£ 754,633$ of governmental funds to reshore manufacturing capacity among its other strategic areas.

Little has been written of the UK government's support of manufacturing reshoring strategies (Bailey \& De Propris, 2014) and, to the best of our knowledge, no scholarly work has yet examined reshoring-oriented policies at the regional level.
This is rather surprising, given that locally implemented reshoring policies tend to descend from nationally designed industrial policies (Grappi et al., 2018; Sirilertsuwan et al., 2019).

\section{Manufacturing Reshoring and Technological Pull Factors}

Technological change has always driven social and economic progress. The 2010s saw the emergence of a wave of new digital technologies linked to the Fourth Industrial Revolution, which has been radically changing business models, manufacturing processes, and firms' value propositions. Their adoption has been translated into more digitalized (Ancarani \& Di Mauro, 2018; Butollo, 2020; Dachs, Kinkel \& Jäger, 2019) and automated manufacturing processes (Ancarani \& Di Mauro, 2018; Ancarani et al., 2019; Moradlou et al., 2017), often referred to as Industry 4.0 (Kiel, Müller, Arnold \& Voigt, 2017; McKinsey \& Company, 2015). For example, the Amazon Effect has disrupted established logistics systems with quicker transportation time between the warehouse and the final consumer (Lieb \& Lieb, 2016). This has pushed several US firms to adopt a reshoring strategy to become more flexible in their processes and be able to respond more promptly to consumers in local markets. By investing in Industry 4.0 technologies, firms aim to cut production costs and become more efficient (Ancarani et al., 2019) as well as providing test-bed solutions through additive manufacturing (Moradlou et al., 2017).

It is still unclear whether the adoption of Industry 4.0 technologies can be considered as a pull factor for manufacturing reshoring, because our understanding of how such new technologies will change production processes and supply chains is still incomplete. Firstly, Industry 4.0 cannot be implemented only at the shop-floor level; instead, new technologies are likely to permeate all of the firm's functions, from its back-office to its marketing activity. This is because the firm is an organic environment and a change in a single part influences the performance of others (Dachs et al, 2019). Secondly, Industry 4.0 needs different skills to be implemented, such as coding capacity, advanced computing skills and multidisciplinary knowledge, as well as soft skills in communication, design thinking, and logical capabilities (Ancarani et al., 2015). Lastly, Industry 4.0 requires an adequate technological infrastructure such as telecommunications, or a robust policy in favor of intellectual property (IP) protection and data privacy (Gadde \& 
Jonsson, 2019; Keller \& Zoller-Rydzek, 2019). Overall, the adoption of new technologies is argued to encourage manufacturing reshoring strategies if this branches out into the firm's network (Ancarani et al., 2019; Fratocchi \& Di Stefano, 2019).

\section{Manufacturing Reshoring and the Role of Local actors as Pull Factors}

According to Ashby (2016) and Baraldi et al. (2018), the most major challenges for a regional economy to host a manufacturing reshoring strategy can be the lack of a skilled labor force and unavailability of local suppliers. So, the presence of local production systems with dense networks of suppliers and skilled labor is crucial to convince firms that they can reshore either the whole or part of their production into a specific local area (Forte \& Miotti, 2015). Indeed, reshoring often requires firms to be able to substitute international suppliers with those embedded in their local industrial cluster (Lavissière et al., 2016; Srai \& Ané, 2016) with relevant capabilities in the local economy (Bailey \& De Propris 2014; Gadde \& Jonsson, 2019; Ketokivi, Turkulainen, Seppälä, Rouvinen \& Ali-Yrkkö, 2017; Nujen et al., 2019; Wan, Orzes, Sartor \& Nassimbeni, 2019). When reshoring is coupled with upgrading ambitions, firms tend to seek local partners (business or research) with greater or more specialized competences than the international ones (Pal, Harper \& Vellesalu, 2018). This is because a dense and well-developed network of suppliers offers not only opportunities for collaboration but also a competitive benchmark for continuous growth. In addition, access to skilled workers can be the result of synergies between local universities and industries that collaborate through joint research or professional apprenticeship projects to nurture new talent (Gadde \& Johsson, 2019; Gylling, Heikkilä, Jussila \& Saarinen, 2015).
Drawing on the above literature review, Figure 1 illustrates the conceptualization of manufacturing reshoring strategy in this work. More specifically, the model examines the factors that might influence companies' manufacturing reshoring decisions and sheds light on how the interactions between such factors revive regional manufacturing reshoring decisions that contribute to strengthening a company's position in its regional value chains.

\section{RESEARCH METHODOLOGY}

This work is based on qualitative primary data collected via in-depth interviews and complemented by secondary information from various sources in order to obtain a holistic understanding of manufacturing reshoring in the West Midlands. The combination of these two methods has not just allowed us to triangulate our data in order to ensure the validity of our understanding of the examined manufacturing reshoring strategies, but also provided greater confidence in our research results (Eisenhardt, 1989; Ghauri, Grønhaug \& Strange, 2020; Gobo, 2004; Hillebrand, Kok \& Biemans, 2001; Jick, 1983; Nielsen et al., 2020).

To warrant the validity of our findings, we followed a rigorous data collection process that included a very thorough examination of primary data with senior managers and policy-makers (Welch \& Piekkari, 2017). The primary data were collected from December 2018 to August 2019 and generated a significant information bank that formed the case study's database. The secondary sources included widely available archival data hosted in public repositories, archival trade press, official websites, and firms' internal documentation such as financial statements (Fenton \& Procter, 2019; Ghauri et al., 2020; Grey, 2020). In addition, to better understand the local industrial system, the
Figure 1 The conceptual model. Source: Authors.

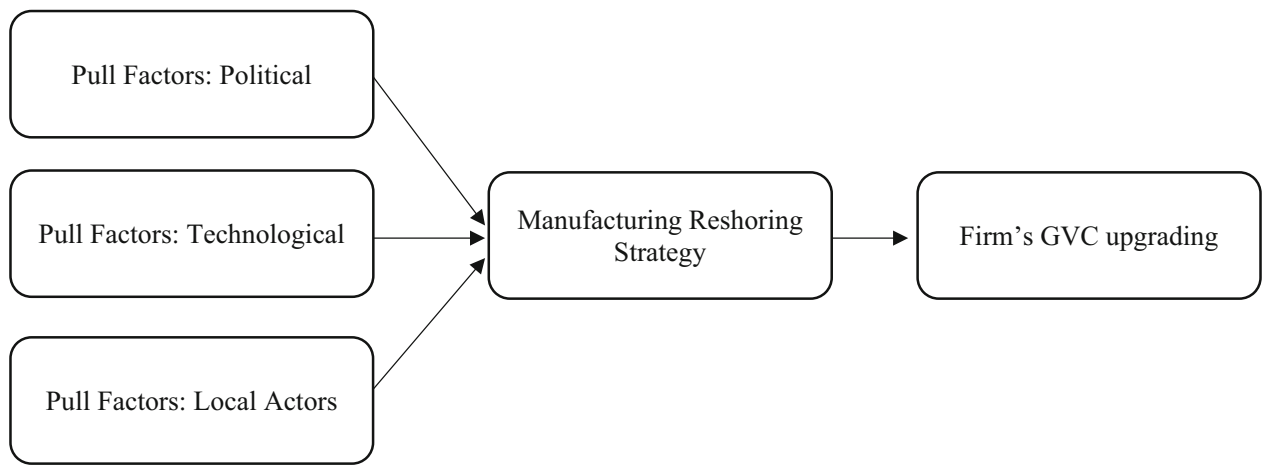


material from the case study was supplemented with interviews with key local stakeholders: the Director of Reshoring UK and a member of the Black County Chambers of Commerce (BCCC). The latter provided insights into the initiatives supporting manufacturing reshoring strategies in the region and in the UK more widely, as well as aiding understanding of the vibrant community of manufactures based in the West Midlands.

The choice of the case study approach in this work is based on the following. First, a case study methodology has been advocated by various scholars as a preferable method of gaining a wideranging understanding of reshoring (Barbieri, Ciabuschi, Fratocchi \& Vignoli, 2018; Di Mauro, Fratocchi, Orzes \& Sartor, 2018; Robinson \& Hsieh, 2016). Such an approach enables comprehensive sense-making of spatially bounded reshoring over the examined time. Second, a case study allows light to be shed on the mechanisms behind the complexities of the local context in which policies regarding reshoring are being developed, set, and implemented (Welch, Piekkari, Plakoyiannaki \& Paavilainen-Mäntymäki, 2011). Third, it gives a widespread opportunity to evaluate the local policies available for adopting and/or supporting manufacturing reshoring strategies (Piekkari \& Welch, 2004; Yin, 2012; Ghauri et al., 2020). Finally, it also offers a good possibility to examine sensitive topics (e.g., trust and cultural differences in relationships with suppliers) that are essential for exploring reshoring decisions in more depth (Fernandez-Stark \& Gereffi, 2019).

We decided to base our work on a single company located in the West Midlands region in order to illustrate the conceptualization of our framework presented above. The company was chosen for its following characteristics (Eisenhardt \& Graebner, 2007; Siggelkow 2002, 2007). First, it operated in a manufacturing sector. Second, it was located in one of the UK's most manufacturingintensive regions in the country with a good pool of tool-making firms that serve the automotive, aerospace, rail, and defense sectors of UK industry (WMCA, 2020; Eurofound, 2019). Third, it was part of a GVC. Fourth, it adopted a reshoring strategy itself due to support the region offered to revive manufacturing activities. Finally, it was seen to significantly contribute to manufacturing reshoring activities in the region (Bailey \& De Propris, 2014).

The selection of stakeholders for the case study followed a rigorous process and consisted of the following steps. First, the analysis of the local trade press was undertaken using the Lexis Nexis database, using the keywords logic approach, such as, "manufacturing" and "reshor" OR "re-shor" AND "West Midlands" while searching the online portal of newspaper articles (Arikan, Koparan, Arikan \& Shenkar, 2019; Awate, Larsen, Mudambi, 2015). Second, local policies aimed at attracting investments were identified by reviewing white papers from several authorities (e.g., West Midlands Combined Authority, Gov.UK, West Midlands Growth Company, the City-REDI blog). Table 1 shows selected initiatives, their aims, funders, as well as a type of upgrading. Finally, all gathered information was then matched by linking the name of the firms (in step 1) with the implemented local policies (in step 2) in order to create a list of companies that adopted manufacturing reshoring strategies with the support of local policies in the West Midlands. This matching led to the selection of three companies and four industrial stakeholders in the West Midlands region.

To ensure a holistic view of our data, we conducted in-depth interviews. We contacted our potential interviewees first by e-mail and then by phone. The e-mail introduced the aim and scope of the research and great effort was made to contact senior managers engaged in various functional areas. Once potential interviewees expressed an interest in taking part in the study, a telephone call was made to provide more information about the research and agree on a suitable date and time for an interview. A practitioner-oriented report was also offered during the telephone conversation in order to further increase interest in the study (Chidlow \& Ghauri, 2015; Ghauri et al., 2020). Overall, we sent three e-mails, one to each firm's CEO, and four to the industrial stakeholders. Only one CEO and two stakeholders agreed to take part in the study. These formed the basis for the case study (Table 2).

The interviews with the firm representative, the Director of Reshoring UK and a member of the Black County Chambers of Commerce were undertaken in English either face-to-face or online via Skype. The interviews were semi-structured with a set of pre-determined open-ended questions but not limited to them. They lasted between 1.5 and 2 hours. Under the agreement of confidentiality and anonymity, all interviews were recorded and transcribed within $24 \mathrm{~h}$ of the interview in order to minimize loss of information (Miles \& Huberman, 1984, 1994). All interview transcripts were coded 
Table 1 Selected political initiatives available in the West Midlands region.

\begin{tabular}{|c|c|c|c|c|}
\hline Policy & Aim & Funders & Support & Upgrading \\
\hline $\begin{array}{l}\text { Pull Factors: } \\
\text { Technological } \\
\text { High-Speed Two } \\
\text { (HS2) Funding } \\
\text { Allocation }\end{array}$ & $\begin{array}{l}\text { Project to connect London/ } \\
\text { Birmingham/Manchester/ } \\
\text { East-Midlands and Leeds } \\
\text { with high-speed trains } \\
\text { (2017-2033) }\end{array}$ & $\begin{array}{l}\text { Manufacturing } \\
\text { Reshoring Strategy } \\
\text { National Government }\end{array}$ & $\begin{array}{l}\text { Firm's GVC upgrading } \\
£ 50.1 \text { bn }\end{array}$ & $\begin{array}{l}\text { Sectors: } \\
\text { Construction Sector and } \\
\text { Local Transportation } \\
\text { System }\end{array}$ \\
\hline $\begin{array}{l}\text { Pull Factors: Local } \\
\text { Actors } \\
\text { New Digital } \\
\text { Infrastructure } \\
\text { Investment Fund } \\
\text { (part of National } \\
\text { Industrial } \\
\text { Strategy) }\end{array}$ & $\begin{array}{l}\text { Commitment from } \\
\text { government to support, } \\
\text { facilitate, and drive } \\
\text { connectivity } \\
\text { (implementation of Digital } \\
\text { Infrastructure Toolkit) }\end{array}$ & National Government & $\begin{array}{l}£ 1 \mathrm{bn}(€ 1.13 \mathrm{bn}) \text { of } \\
\text { public investment, } \\
\text { including } \\
£ 176 \mathrm{~m}(€ 200 \mathrm{~m}) \text { for } 5 \mathrm{G} \\
\text { and } £ 200 \mathrm{~m}(€ 227 \mathrm{~m})\end{array}$ & $\begin{array}{l}\text { Sectors: } \\
\text { Digital Infrastructure }\end{array}$ \\
\hline $\begin{array}{l}\text { Corporation Tax } \\
\text { relief on Research } \\
\text { and Development } \\
\text { (R\&D) Project }\end{array}$ & $\begin{array}{l}\text { Support companies in } \\
\text { performing } R \& D \text { innovative } \\
\text { project }\end{array}$ & $\begin{array}{l}\text { Dept for Business, } \\
\text { Energy \& Industrial } \\
\text { Strategy }\end{array}$ & $\begin{array}{l}\text { SMEs: } 230 \% \text { deduction } \\
\text { on qualifying costs from } \\
\text { yearly profit } \\
\text { Research and } \\
\text { Development } \\
\text { Expenditure Credit } \\
\text { (RDEC): } 12 \% \text { Tax } \\
\text { Credit (1/01/2018-31/ } \\
03 / 2020) 13 \% \text { from } 1 / \\
4 / 2020\end{array}$ & $\begin{array}{l}\text { The project must create an } \\
\text { advance in the overall sector } \\
\text { in which the company } \\
\text { operates. }\end{array}$ \\
\hline $\begin{array}{l}\text { Black Country EU } \\
\text { Structural and } \\
\text { Investment Fund } \\
\text { Strategy }\end{array}$ & $\begin{array}{l}\text { Investments in Business, } \\
\text { Place, and People to address } \\
\text { barriers to growth, areas of } \\
\text { market failure, innovation } \\
\text { and social exclusion }\end{array}$ & Black Country LEP & $\begin{array}{l}£ 141 \mathrm{~m} \text { of EU Structural } \\
\text { and Investment Fund }\end{array}$ & $\begin{array}{l}\text { Sectors: } \\
\text { Transport Technologies } \\
\text { (Aerospace and } \\
\text { Automotive), Building } \\
\text { Technologies, Advanced } \\
\text { Manufacturing, } \\
\text { Environmental } \\
\text { Technologies, Business } \\
\text { Services }\end{array}$ \\
\hline $\begin{array}{l}\text { IDP14: } \\
\text { accelerating the } \\
\text { transition to zero } \\
\text { emission vehicles } \\
\text { (research and } \\
\text { development) }\end{array}$ & $\begin{array}{l}\text { This is to enable industry-led } \\
\text { research into vehicle } \\
\text { technologies that } \\
\text { accelerates the transition to } \\
\text { zero emission vehicles. In } \\
2050 \text {, all cars and vans in } \\
\text { the UK should be zero- } \\
\text { emission vehicles }\end{array}$ & $\begin{array}{l}\text { Office for Low Emission } \\
\text { Vehicles (OLEV) and } \\
\text { Innovate UK via the } \\
\text { Faraday Industrial } \\
\text { Strategy Challenge } \\
\text { Fund }\end{array}$ & $£ 18 \mathrm{~m}$ & $\begin{array}{l}\text { Sectors: } \\
\text { Transportation and } \\
\text { Automotive }\end{array}$ \\
\hline $\begin{array}{l}\text { West Midlands } \\
\text { Local Industrial } \\
\text { Strategy }\end{array}$ & $\begin{array}{l}\text { To drive growth, } \\
\text { productivity, and innovation } \\
\text { throughout the region of } \\
\text { West Midlands }\end{array}$ & $\begin{array}{l}\text { West Midlands } \\
\text { Combined Authority } \\
\text { with LEPs }\end{array}$ & $\begin{array}{l}\text { Skills Deal: } £ 69 \text { m } \\
\text { Faraday Battery } \\
\text { Challenge Fund award } \\
\text { to Warwick } \\
\text { Manufacturing Group } \\
\text { (WMG): } £ 80 \mathrm{~m} \\
\text { National Automotive } \\
\text { Innovative Centre: } £ 15 \\
\text { m } \\
\text { WMG's Energy } \\
\text { Innovation Centre: } £ 13 \\
\text { m } \\
\text { 5G Testbed: } £ 50 \mathrm{~m}\end{array}$ & $\begin{array}{l}\text { Sectors: } \\
\text { Low Carbon Technology, } \\
\text { Aerospace, Logistic/ } \\
\text { Transport Technology, } \\
\text { Metals \& Material, Life } \\
\text { Sciences, Professional } \\
\text { Skills, Rail, Construction, } \\
\text { Creative, Food \& Drink, } \\
\text { Automotive, Tourism }\end{array}$ \\
\hline
\end{tabular}


Table 1 (Continued)

\begin{tabular}{|c|c|c|c|c|}
\hline Policy & Aim & Funders & Support & Upgrading \\
\hline $\begin{array}{l}\text { Growing Places } \\
\text { Fund (GPF) }\end{array}$ & $\begin{array}{l}\text { Budget available for local } \\
\text { enterprise partnerships } \\
\text { (LEPs) for short-term } \\
\text { economic development } \\
\text { activities to unlock jobs and } \\
\text { growth in the area }\end{array}$ & $\begin{array}{l}\text { LEPs Coventry \& } \\
\text { Warwickshire (CWLEP) } \\
\text { - Department for } \\
\text { Communities and } \\
\text { Local Government }\end{array}$ & $£ 12 \mathrm{~m}$ & $\begin{array}{l}\text { Sectors: } \\
\text { Advanced Manufacturing } \& \\
\text { Engineering }\end{array}$ \\
\hline $\begin{array}{l}\text { BCRS Business } \\
\text { Loans }\end{array}$ & $\begin{array}{l}\text { Loans to help small and } \\
\text { medium-sized businesses } \\
\text { develop and grow }\end{array}$ & $\begin{array}{l}\text { Department for } \\
\text { Business, Energy \& } \\
\text { Industrial Strategy }\end{array}$ & $£ 10,000-£ 150,000$ & $\begin{array}{l}\text { Start-Up and New } \\
\text { Businesses }\end{array}$ \\
\hline $\begin{array}{l}\text { National retraining } \\
\text { scheme (i.e., Get } \\
\text { Help to Retrain) }\end{array}$ & $\begin{array}{l}\text { To support adults in } \\
\text { retraining for better jobs } \\
\text { and preparing them for } \\
\text { future changes to the } \\
\text { economy such as } \\
\text { automation and } \mathrm{Al}\end{array}$ & $\begin{array}{l}\text { Department for } \\
\text { Education }\end{array}$ & $£ 2.5 \mathrm{bn}$ & Society - Digital Skills \\
\hline
\end{tabular}

Source: Authors.

Table 2 A brief description of the examined cases.

\begin{tabular}{|c|c|c|c|c|c|c|}
\hline Cases & Country & Area & Entity & Relevance & $\begin{array}{l}\text { Interviewee } \\
\text { role }\end{array}$ & $\begin{array}{l}\text { Mode of } \\
\text { interview }\end{array}$ \\
\hline 1 & UK & $\begin{array}{l}\text { West } \\
\text { Midlands }\end{array}$ & Firm & Adopted a MNF Reshoring Strategy & CEO & Skype \\
\hline 2 & UK & UK & $\begin{array}{l}\text { Industrial } \\
\text { Association }\end{array}$ & $\begin{array}{l}\text { Website offering matching services w/UK } \\
\text { Suppliers }\end{array}$ & Director & Face-to-Face \\
\hline 3 & UK & $\begin{array}{l}\text { West } \\
\text { Midlands }\end{array}$ & $\begin{array}{l}\text { Chamber of } \\
\text { Commerce }\end{array}$ & Supporting firms in relocation activities & Manager & Face-to-Face \\
\hline
\end{tabular}

Source: Authors.

and analyzed in NVivo according to the reshoring factors (Table 3 in Appendix).

The interpreted text represented a proxy of the phenomenon related to manufacturing reshoring (Ryan \& Bernard, 2000). More specifically, the pull factors discussed above were used as proxies to identify whether (a) in the West Midland, the locally implemented reshoring policy was inclusive sustaining as well as attracting manufacturing reshoring activities; (b) incentives for investments in automation (part of locally implemented reshoring policy) and for the up-skilling of the workforce encourage local firms to adopt a manufacturing reshoring strategy in the West Midlands; (c) the cooperation between firms and local actors to carry out a reshoring strategy was delivering additional value in the region; and (d) if the overall reshoring strategy adopted by firms sustained by the locally implemented reshoring policy that could have resulted in upgrading the value creation of both firms and the region.

\section{CASE STUDY: OVERVIEW AND ANALYSIS}

Overview of the West Midlands Region

The West Midlands region is located at the center of England and was the birthplace of the First and Second Industrial Revolutions. However, since the 1960s, the region has experienced a gradual and steady decline linked to the offshoring and restructuring of its manufacturing industries (Donnelly, Begley \& Collis, 2017). The delocalization of manufacturing low-value-added activities from the region to lower-cost countries occurred in parallel with the constant upgrading of what manufacturing was left thanks to the adoption of the latest technologies to produce top-end high-value outputs (Bryson, Daniels \& Warf, 2013). This allowed, for instance in automotive, local manufacturing companies to remain internationally competitive throughout the 1990s and 2000s. 
Although the growing international network of first-, second-, and third-tier suppliers allowed original equipment manufacturers (OEMs) to increase their profit in the UK between 1996 and 2006, the global value added (GVA) to gross domestic product (GDP) ratio dropped by $40 \%$ and employment in automotive fell by 7\% (Bailey, Kobayashi \& MacNeill, 2008). Even though such a significant decrease impoverished the local industrial base in terms of skilled workers, investments, and infrastructure, the advanced manufacturing operations that are still located in the region today are absolutely world-class. For example, the region not only still proudly hosts major automotive players (such as Jaguar Land Rover, Nissan, and Aston Martin), but it also supports the growth of smaller companies (e.g., Geely London Electric Vehicle Company) (The Independent, 2014; WMCA, 2019).

Having said that, over the last decade, manufacturing in the West Midlands has faced several new challenges. On one hand, the global financial crisis of 2008 caused a global contraction of final markets for automotive OEMs as well as frictions in automotive GVCs. On the other hand, a wave of new technologies has started to revolutionize automotive production processes, firms' business models, and products themselves. In a changing global environment, the shift from petrol cars to electric cars is testing the ability of the industry to adopt new technologies and to flexibly manage a decomposition of the supply chain and therefore very complex relationships with overseas suppliers with long lags to deliver to the final market. Evidence suggests that firms started timidly to either relocate part(s) of their entire production back to their home country or to choose domestic suppliers over foreign ones. More specifically, in 2011, British-led firms in the automotive sector sourced $36 \%$ of their components locally, while in 2017 this had increased to 44\% (Holweg, Davies \& Wood, 2017).

\section{Locally Implemented Reshoring Policies}

At the regional level, the National Industrial Strategy was expected to be implemented by local policy actors, such as the West Midlands Combined Authority (WMCA), composed of the Black Country, Coventry, and Warwickshire as well as the Greater Birmingham and Solihull local enterprise partnerships. The WMCA was to promote the West Midlands Local Industrial Strategy in the first half of 2019 by focusing mostly on high-tech manufacturing industries such as automotive, aerospace, and rail. In particular, the UK government was committed to unlocking up to $£ 69 \mathrm{~m}$ in a Skills Deal in the West Midlands, to allocate $£ 80 \mathrm{~m}$ to the Faraday Battery Challenge Fund awarded to the Warwick Manufacturing Group (WMG), to support the $£ 150 \mathrm{~m}$ National Automotive Innovation Centre and other initiatives not directly related to manufacturing industry (e.g., the Transformative Cities Fund) (UK government, 2018; 2017).

\section{The Reshoring Case Study: From International Outsourcing to In-house Production}

This case study revolves around a medium-sized enterprise that we called Alpha, for anonymity, which is located in Coventry, a city in the West Midlands. Alpha specializes in component-making and provides engineering and electrical solutions to firms (i.e., OEM); the company acts as a first-tier supplier in the automotive sector in the West Midlands region. In 2011, it become the sole supplier of a specific electronic component to a local leading automaker. The manufacturing of this electronic component was outsourced to a Chinese second-tier supplier, part of Alpha's supply network, the same year. However, in 2014 this production was reshored in-house in purpose-built manufacturing facility in Coventry (Fig. 2 in Appendix).

The reshoring strategy required Alpha to carry out a large greenfield fixed investment in new machinery. This was realized thanks to public funding from the local enterprise partnership (LEP) in collaboration with research centers in nearby universities via the Innovate $U K$ initiative. The investment not only allowed to adopt a manufacturing reshoring strategy, but it also paved the way for the upgrading of the company to become an original design manufacturer (ODM) in the electric vehicles (EVs) market and to expand its value chain in advanced engineering services to lead-, non-lead firms in the automotive industry. This responded squarely to one of the strategic sectors targeted by the UK government.

Alpha's reshoring journey actually began in 2011, when the product outsourced to the Chinese supplier was delivered with some faults. The Chinese relationship was established in 2006 and lasted 5 years without any conflicts. However, once the Chinese supplier started to outsource parts of the electronic component-making to other subsuppliers, the quality of its products started to fall below the agreed standards. So, in 2011 tensions between the two parties started to appear due to the 
knock-on effect on Alpha's inability to deliver highquality components on time to its lead firms at home. Such incompetence started to significantly affect Alpha's credibility as a reliable first-tier supplier within the automotive sector in the region. At that point, the company supplied one main car maker. As the CEO stated:

\begin{abstract}
They didn't really understand what they were doing, they did not understand the design and also they couldn't really make what we wanted. We've got to the stage where we wanted to get some product from them, but we hadn't realized their difficulty in sourcing some of the components. [Chinese Supplier's employees] were not helping because they just changed the entire design and all of the components, which were already tested and signed off. [The Chinese supplier's] costs were low, but their ability to deliver was not so good. And the problem we faced was we didn't have the machining necessary for making the components of the aluminum part. So, I took the decision not to carry on with the Chinese supplier.
\end{abstract}

The relationship between Alpha and the Chinese supplier came to an end in 2014 for the following reasons: (i) poor communication between Alpha and the Chinese supplier because of cultural issues, (ii) unacceptable delivery delays due to several errors in the product delivery, and (iii) the incapacity of the Chinese supplier to deliver the product in compliance with the specifics and requested quality. It is important to point out that the aluminum electronic components are difficult to make since they must present specific features to comply with the International Organisation for Standardization (ISO) certifications, which are necessary in the automotive sector.

Shortly after the relationship with the Chinese supplier ended, Alpha gave its contract to a supplier located in Poland suggested by the lead firm. However, as recalled by the CEO himself "they [the Polish supplier] could not do it either".

So, still mindful of the negative experience with the Chinese supplier and the quick turnaround requested by the lead firm, Alpha started seriously considering making the electronic component inhouse. As stated by the CEO, "In the end, I decided to do some research ... Could we buy a machine and could we buy in some expertise in the UK to make this part ourselves and do it all at our source? And that's what we did."

This decision opened up a totally new opportunity for Alpha in the manufacturing and engineering facilities in the local workshop, even though the company faced some challenging issues related to the lack of skills and machineries locally.

\section{The Role of Locally Implemented Policies}

In 2014, when Alpha's management decided to reshore the production of an aluminum electronic component, the company won a grant to fund a large investment to expand its new facility in Coventry. Out of the $£ 400,000$ requested for the expansion, Alpha managed to secure almost half of the funding, which helped the company bring the production of that single electronic component inhouse. What is more, it also allowed the company to acquire new competencies that significantly contributed not only to winning more new contracts in the automotive and defense industries but also being eventually involved in the electric vehicles value chain. Further, the company was also able to source more locally from other local suppliers based in the West Midlands.

Alpha's funding came from the Growing Place Fund (GPF), the UK government-level initiative established in 2014, which aimed at supporting local business in unlocking wider economic growth and creating jobs by "allowing local enterprise partnerships to prioritize the infrastructure they need and empowering them to deliver their economic strategies" (Department for Transport, 2011: 2).

It is worth noting that the GPF initiative's objective was to ensure and promote regional economic development, without prioritizing specific industries. It was managed by the local enterprise partnership (LEP), business-led partnerships between local authorities and local private sector businesses. There are 38 LEPs across England and their purpose is to match regional economic priorities with funding linked to national government initiatives with the aim of driving economic growth and creating jobs in local areas. This policy initiative highlights a way via which a national government policy for local development decentralized the implementation and the funding allocation to the LEP due to its knowledge of local economic priorities.

\section{The Role of Technology}

Once it was decided to reshore, Alpha was well aware of the complexity of the implications, mainly because at first they lacked the competences and the necessary machinery. So, the decision to adopt a manufacturing reshoring strategy became strictly linked to a recognition that they did not have the right capital investment to carry it through. Indeed, the expansion of production in Coventry was coupled with investment in a new 
piece of modern machinery. To add a further layer of complexity, once the new machinery was set up, Alpha had to hire local workers capable of operating it. In addition to the actual investment, the company's management spent a significant amount of time acquiring the relevant knowledge and skill to be able to operate the machinery in order to ensure the production of good-quality products. As stated by the CEO:

\begin{abstract}
We started from zero to having two machines, and we bought them at $£ 185,000$ for the two machines and we hired a guy that had experience in working with these machines. And that was a very brave decision because we never made anything like that before. We weren't able to run the machines, so we had to learn how to operate them. We wanted to know every machine's part, how to do it, so we learnt by ourselves. It took us about 12 months to buy the machine, learn how to use it, train the person, and get to the point where we could produce something that was acceptable. And that's what we did.
\end{abstract}

As a company, Alpha had a good relationship with its lead firm. However, when the latter was informed about Alpha's decision to make the product internally, it expressed its concerns not only about Alpha's capabilities but also the cost margins due to higher labor costs in the UK. With regard to capabilities, Alpha reassured the lead firm that it had already hired competent personnel and trained the existing workforce. As to the labor cost, Alpha restored the lead firm's confidence by pointing out all the issues the company encountered with the Chinese supplier in relation to ISO and delivery times, the amount of time and cost spent on travels to/from China, as well as the cost associated with establishing a trustworthy working relationship. The intangible costs had an impact on the daily routine of Alpha's management that caused significant delays with other customer requests. Therefore, by bringing the production of the electronic component in-house, Alpha was convinced it could overcome any problems, as it was able to better control each phase of the production and also offer a more reliable and highest-quality product. Alpha's confidence in delivering the required product persuaded the lead firm to buy from it, even though the price was not lower but close to that of the Chinese supplier. As recalled by the CEO:

To start with, [the lead firm] was very worried [...] because they didn't know if it was going to be OK. [...] But once we started producing the first part, then they realized that we could do it. Then, the second part of worries was about 'can you match the price that we would have found if we'd gone to China?' [...] all those grey numbers are actually added in the price, you can find that made in the UK is cheaper, at least the same price. Another big thing is that you have the control over, we didn't have the control over quality or communication when it was in China, that's why we did it.

\section{The Role of Local Actors}

Local suppliers are among the most important local actors for supporting the manufacturing reshoring strategy. Once Alpha decided to reshore, new machinery was ordered. When it arrived, it was assembled by the seller, but nobody was told how to use it. So, the company's management began looking for local suppliers that were able to provide assistance with the machinery. In doing so, the company discovered a flourishing network of suppliers whom the company could refer to for advice. Alpha was rather surprised to find that some local tool-making firms were able to operate the machinery. These collaborations are still ongoing, as stated by the CEO:

So, when we say goodbye to the Chinese supplier, we were sorted on our own, but ... I thought ... quite naïve ... that when you buy a machine it comes with all the tools that you need actually to machine the part ... it doesn't. It's only the machine that comes. You then need to go to a tooling company; they will sell you the tools that go into the machinery. Well, the machine manufacturer, the tooling company, and the software providers are still with us today and they are still supporting us.

In addition to the local network of suppliers, industrial associations such as the GMTA and the BMTA also played a relevant role in shaping Alpha's approach in its manufacturing reshoring strategy. This is because they not only encompassed general manufacturers but also were part of the national online initiative Reshoring UK: UK Engineering Marketplace. This online platform allowed Alpha access to collaborations with leading industrial engineering associations as well as trusted, accredited suppliers that were capable of delivering products and services that matched their own requirements. As stated by the Director of Reshoring UK:

The idea to use trade associations is that it is sustainable because trade associations know who their members are, and they can obviously keep the data updated. And the other key point about how we managed to get the other trade associations to be involved, bearing in mind we are an association itself [...] I want to demonstrate how important it is, if the government don't. We need to demonstrate that we have these abilities and I think more and more companies feel the need to connect with others. 
What is more, Alpha's access to other local actors (e.g., local universities, the LEP, Chambers of Commerce) has also helped the company to obtain the relevant knowledge and connections necessary to develop new solutions for products and services related to EVs. As pointed out by the CEO:

\begin{abstract}
We always have some support from the Chambers of Commerce, universities, and local enterprise partnership, Coventry University ... a lot of things are going on in Coventry, but also places where people set up other business are really good centers for knowledge-sharing where you can find out things and also some of our friends that are making things as well even to the point of the suppliers ...
\end{abstract}

Thanks to its reshoring strategy, Alpha was able to acquire new competencies in the production of lightweight components that could feed not only into the automotive internal combustion engine and defense supply chains but also crucially into the new and expanding EV value chain. Indeed, lightweight components in aluminum are very important for EVs, as they tend to compensate for big and heavy batteries especially when battery life depends on the weight of a car. As the EV value chain in the West Midlands is driven by big players (such as Jaguar Land Rover and Nissan), Alpha was able to plug itself in a local network of suppliers based in the West Midlands.

The Black Country Chamber of Commerce (BBBC) located in the West Midlands was extremely proactive in upgrading the skills of the local workforce in order to meet the changing and growing demand of local manufacturers, in assisting firms to recruit the right staff and provide a safe network of enterprises where best practices could be shared amongst leaders. Furthermore, the BCCC acted as a good point of contact when a new company wanted to relocate to the West Midlands because it very quickly put the company in touch with the LEP, who could very promptly assist the newcomer with any requests regarding funding and networking opportunities. Such signposting shows how important it is for a well-functioning industrial system to have key stakeholders working together to support firms that are planning a manufacturing reshoring strategy. According to a manager at the BCCC:

\footnotetext{
Most participated in the peer-to-peer network and group for our managers, owners, CEOs, and leaders because there is not really anywhere to go when they want to solve an issue ... business leaders come together offering strengthening their line of work, best practices for leaders and work together and it's not a selling group.
}

\section{DISCUSSION}

The reshoring case study analyzed above has enabled us to unpack and further our understanding of the effectiveness of a national industrial strategy implemented at the local level aimed at supporting local economic growth by leveraging the ambitions of firms in adopting manufacturing reshoring strategies. Indeed, the locally implemented reshoring policy contributed to recreating and upgrading local value chains in an automotive sector that has deep and historical importance for the West Midlands region of the UK. In doing so, our case study is a good example of how the concerted efforts of key regional stakeholders and the level of a regionally implemented policy help to support a firm's manufacturing reshoring strategy which, in turn, was then able to upgrade the local ecosystem by actively engaging with its local actors.

To Alpha, the turning point in its manufacturing reshoring journey was the opportunity to expand its workshop facilities with new state-of-the-art machinery purchased to make the aluminum electronic component the company used to outsource to foreign suppliers. The investment in this new machinery required an absolute commitment from the company, because it meant upgrading the entire software system as well as the skills of its workforce. Through its manufacturing reshoring strategy, Alpha also triggered supply chain upgrading, by increasing the value contribution to its GVC. Indeed, the company moved along its value chain from being an original equipment manufacturer to an original design manufacturer able to produce its own autonomous EV components (Fig. 2 in Appendix).

This upgrading allowed the firm to expand its international markets by opening trade offices in Australia and the USA. In the EV components' segment, Alpha brought new knowledge in the territory by opening up opportunities for other companies in the region to collaborate in more valuable project (e.g., Warwick Manufacturing Group), to engage in other GVCs (e.g., railway and aerospace) and to attract external capital (e.g., contracts with the UK defense sectors). These elements are at the foundations for our first proposition:

Proposition 1: Manufacturing reshoring strategies upgraded the position of the region in supply chains as it opened opportunities for more valueadding operation in emerging GVCs. 
The critical aspect of this operation was Alpha's readiness to reshore due to its willingness to reorganize its business opportunities within the local environment (Nujen, Halse, Damm \& Gammelsæter, 2018, 2019). It is not easy to embrace strategic change, as any adjustments to current business practices often bring significant financial and non-financial challenges not only within the existing workforce but also the external environment. Alpha, however, was able to overcome such obstacles due to the existence of a dense local support and business system, which greatly assisted the company in operating its machinery, providing the required training and funding opportunities. What is more, this supportive structure also contributed to Alpha's overall positive organization environment, which allowed the company to embark on a smooth manufacturing reshoring journey (Judge \& Duglas, 2009). These results confirm that an inclusive locally implemented industrial policy in the West Midlands was able to support manufacturing reshoring activities in the region. So, our second proposition can be worded as follows:

Proposition 2: Inclusive locally implemented industrial policy enabled manufacturing reshoring activities into a region.

The role of technology in fostering a manufacturing reshoring strategy is doubtless. Without any change in the technological process, manufacturing reshoring would not have been possible. Not only did the investment in technology help Alpha to reshore its electronic components in-house, but it led the company to open up to new sectors with opportunities for further value-chain upgrading. Our finding is in line with the work of Rehnberg \& Ponte (2018) and Strange \& Zucchella (2017) and suggests that Industry 4.0 has a predominant role in shaping the upgrading of firms' GVCs. This result also confirms that manufacturing reshoring strategies can be underpinned by technology adoption (Barbieri et al., 2018; Dachs et al., 2019). Further, our findings shed a novel light on the crossover between Industry 4.0 and reshoring, because the upgrading outcome for Alpha was only possible due to the tacit knowledge the company was able to absorb from its local system, suggesting a positive relationship between the success of the reshoring strategy through Industry 4.0 and the readiness of the local ecosystem. Such findings confirm that technological investment increases the efficiency of the production process in the home economy and that locally implemented industrial policy should not only focus on providing funding for company investments but also foster the local community to support manufacturing reshoring activities in the region. Hence, our third proposition is:

Proposition 3: The technological investment by Alpha fostered innovative capabilities at the regional level.

The role of local actors was also extremely important for the manufacturing reshoring strategy as they helped shape policies and initiatives by fostering a vibrant ecosystem at the regional level. Starting with the Chamber of Commerce (BCCC), its role was to create lively communities of local entrepreneurs and businesses for the exchange of best business practices, sharing knowledge, and experience. The Chambers of Commerce (BCCC) also worked in strict collaboration with the local education system in order to promote apprenticeship and training programs aimed at students in secondary schools. This systemic effort also encompassed several local stakeholders, such as industry associations, that came together to create an online platform to address the matching of needs of local suppliers' demands. Therefore, the more the company cooperated with local actors in support of the manufacturing reshoring strategy, the more value was brought into the region. Finally, these findings suggest our last proposition:

Proposition 4: The systemic commitment of local stakeholders (e.g., universities, industrial association, LEPs) was instrumental in the realization of the reshoring strategy, which has benefitted the whole region by building advanced technology capabilities that spilled over from the firm to the region.

Finally, based on our findings, we can conclude that manufacturing reshoring strategies not only allow the upgrading of a firm's value chain, but also the upgrading of the entire community, as new skills and new industries are interwoven together. In the GVC terminology, the upgrading of a single firm allows the upgrading of the entire regional industrial system by increasing the number of jobs created and funding initiatives supported by the local enterprise partnership. 


\section{CONCLUSION}

The case study presented in this work shows how regional dynamics are pivotal for attracting manufacturing reshoring. More specifically, by embedding our case study in a regional context, this work shows how regional characteristics linked to pull factors change the narrative on reshoring from a national to a regional focus. By doing so, this work demonstrates how regional implementation of industrial policies by local stakeholders working together can create a multiplier effect in the value of the region by increasing the attractiveness of hosting a manufacturing reshoring strategy.

In other words, the pull factors driving reshoring strategies are linked to the specific regional ecosystem in the home economy the firm is looking to move operations back to. Our findings show that a firm's decision to reshore cannot be understood in isolation from the context of the destination as shaped by regional institutions and key actors, policies, and access to relevant technology and talent. In a sort of feedback loop, a successful manufacturing reshoring strategy can trigger upgrading opportunities for the firm, its value chain, and the region.

Although the experience of Alpha's reshoring journey is unique, some more transferable lessons can be learnt. Firstly, the need to regain control over the production process (timing and quality) and product (quality and innovation) might take the firm to an offshoring dead-end, opening the path for a reshoring strategy (there are well-known cases of this, such as Burberrys'). Secondly, the success of Alpha is unlikely to be isolated if the home economy has in place a pro-manufacturing national-level policy and regionally implementable tools to address the specific needs of reshoring firms (for example Aston Martin). Thirdly, the systemic support that reshoring firms receives allows not only a change of location, but likely a form of upgrading. Finally, and crucially, reshoring policies have multiple dividends, as firmlevel decisions were supported by a favorable regional ecosystem, both the firm as well as the region benefitted through a process of technological firm and regional upgrading (see for instance the case of Repowering the Black Country project) (Black Country LEP, 2020).

From a policy point of view, locally implemented industrial policies aimed at supporting industrial regeneration and regional growth can provide the overarching rationale for regionally based initiatives, whose design and implementation also includes encouraging reshoring strategies and supporting firms that embark on that journey, in line with the bottom-up approach of GVC policy interventions (Pietrobelli \& Stariz, 2018). Such policies might even be more prevalent due to the significant impact the Covid-19 pandemic is having on exposing and revealing the fragility of GVCs by urging policy-makers to develop far-reaching policies for dealing with its aftermath (Barbieri et al., 2020; Strange, 2020; van Assche \& Lundan, 2020). An added layer of uncertainty may well be due to Brexit. Given its dense and complex cross-border supply chain exchanges within the automotive value chain, what trade deal - if any - will the UK have after leaving the European Union? The further British businesses are from being able to enjoy frictionless trade, the more cost-inefficient their involvement will be, leading to greater reliance on local suppliers. However, the uprooting of foreign OEMs could fundamentally shake the longer-term survival of some industries, foremost automotive, as key first-tier suppliers might follow OEMs abroad.

\section{ACKNOWLEDGEMENTS}

The authors would like to acknowledge the comments provided on early versions of this article by attendees at JIBP PDW EIBA 2019 as well as David Bailey for his insightful feedback on the very first draft of our paper. We would also like to thank Special Issue Editors Carlo Pietrobelli, Roberta Rabellotti, Ari Van Assche, and three anonymous reviewers for their feedback and guidance. This research was supported by the European Commission under the Horizon 2020- Marie Skłodowska-Curie Actions project MAKERS: Smart Manufacturing for EU Growth and Prosperity (Grant number: 691192).

\section{REFERENCES}

Ancarani, A., \& Di Mauro, C. 2018. Reshoring and Industry 4.0: how often do they go together? IEEE Engineering Management Review, 46(2): 87-96.
Ancarani, A., Di Mauro, C., Fratocchi, L., Orzes, G., \& Sartor, M. 2015. Prior to reshoring: A duration analysis of foreign manufacturing ventures. International Journal of Production Economics, 169: 141-155. 
Ancarani, A., Di Mauro, C., \& Mascali, F. 2019. Backshoring strategy and the adoption of Industry 4.0: Evidence from Europe. Journal of World Business, 54(4): 360-371.

Arik, M. 2013. Framing the offshoring and re-shoring debate: $A$ conceptual framework. Journal of Global Business Management, 9(3): 73-83.

Arikan, I., Koparan, I., Arikan, A. M., \& Shenkar, O. 2019. Dynamic capabilities and internationalization of authentic firms: Role of heritage assets, administrative heritage, and signature processes. Journal of International Business Studies, 50(8): 1-35.

Ashby, A. 2016. From global to local: Reshoring for sustainability. Operations Management Research, 9(3-4): 75-88.

Awate, S., Larsen, M. M., \& Mudambi, R. 2015. Accessing vs sourcing knowledge: A comparative study of $R \& D$ internationalization between emerging and advanced economy firms. Journal of International Business Studies, 46(1): 63-86.

Bailey, D., Corradini, C., \& De Propris, L. 2018. 'Home-sourcing' and closer value chains in mature economies: The case of Spanish manufacturing. Cambridge Journal of Economics, 42(6): 1567-1584.

Bailey, D., \& De Propris, L. 2014. Manufacturing reshoring and its limits: The UK automotive case. Cambridge Journal of Regions, Economy and Society, 7(3): 379-395.

Bailey D., \& De Propris L. 2020. Industry 4.0: and Regional Transformation. London: Taylor and Francis.

Bailey, D., Kobayashi, S., \& MacNeill, S. 2008. Rover and out? Globalisation, the West Midlands auto cluster, and the end of MG Rover. Policy studies, 29(3): 267-279.

Baldwin, R. 2019. The globotics upheaval: Globalization, robotics, and the future of work. Oxford: Oxford University Press.

Baldwin, R., \& Venables, A. J. 2013. Spiders and snakes: Offshoring and agglomeration in the global economy. Journal of International Economics, 90(2): 245-254.

Baraldi, E., Ciabuschi, F., Lindahl, O., \& Fratocchi, L. 2018. A network perspective on the reshoring process: The relevance of the home-and the host-country contexts. Industrial Marketing Management, 70: 156-166.

Barbieri, P., Boffelli, A., Elia, S., Fratocchi, L., Kalchschmidt, M., \& Samson, D. 2020. What can we learn about reshoring after Covid-19?. Operations Management Research. https://doi.org/ 10.1007/s12063-020-00160-1.

Barbieri, P., Ciabuschi, F., Fratocchi, L., \& Vignoli, M. 2018. What do we know about manufacturing reshoring? Journal of Global Operations and Strategic Sourcing 11(1): 79-122.

Barnow, B.S., \& Hobbie, R.A. 2013. The American Recovery and Reinvestment Act: The Role of Workforce Programs. http:// research.upjohn.org/cgi/viewcontent.cgi?article= $1241 \&$ context=up_press. Accessed 02 June 2020.

Beugelsdijk, S., McCann, P., \& Mudambi, R. 2010. Introduction: Place, space and organization-economic geography and the multinational enterprise. Journal of Economic Geography, 10(4): 485-493.

Beugelsdijk, S., \& Mudambi, R. 2013. MNEs as border-crossing multi-location enterprises: The role of discontinuities in geographic space. Journal of International Business Studies, 44(5): 413-426.

Black Country LEP. 2020. Repowering the Black Country. Available at https://www.blackcountrylep.co.uk/upload/files/ Repowering\%20the\%20Black\%20Country\%20A\% 20 prospectus $\% 20$ to\%20lead $\% 20 a \% 20$ clean $\% 20$ growth\% 20 revolution\%20in\%20the\%20UK.pdf?utm_source= miragenews\&utm_medium=miragenews\&utm_campaign= news. Accessed 02 Feb 2021.

Boschma, R. 2015. Towards an evolutionary perspective on regional resilience. Regional Studies, 49(5): 733-751.

Bryson, J., Daniels, P., \& Warf, B. 2013. Service worlds: People, organisations, technologies. London: Routledge.

Butollo, F. 2020. Digitalization and the geographies of production: Towards reshoring or global fragmentation? Competition \& Change. https://doi.org/10.1177/1024529420918160.
Canham, S, \& Hamilton, R. T. 2013. SME internationalisation: Offshoring, "backshoring", or staying at home in New Zealand. Strategic Outsourcing: An International Journal, 6(3): 277-291.

Cantwell, I. 2009. Location and the multinational enterprise. Journal of International Business Studies, 40(1): 35-41.

Chen, L., \& Lombaerde, P. D. 2019. ASEAN between globalization and regionalization. Asia Pacific Business Review, 25(5), 729-750.

Chidlow, A., \& Ghauri, P. 2015. What incentives are being used by international business researchers in their surveys: A review. The William Davidson Institute, The University of Michigan. Academic Working Paper Series, No 1086 (January).

Chidlow, A., Holmström-Lind, C., Holm, U., \& Tallman, S. 2015. Do I stay or do I go? Sub-national drivers for post-entry subsidiary development. International Business Review, 24(2): 266-275.

Chidlow, A., Salciuviene, L., \& Young, S. 2009. Regional determinants of inward FDI distribution in Poland. International Business Review, 18(2): 119-133.

Crescenzi, R., Pietrobelli, C., \& Rabellotti, R. 2014. Innovation drivers, value chains and the geography of multinational corporations in Europe. Journal of Economic Geography, 14(6): 1053-1086.

Dachs, B., Kinkel, S., \& Jäger, A. 2019. Bringing it all back home? Backshoring of manufacturing activities and the adoption of industry 4.0 technologies. Journal of World Business, 54(6): 10117.

De Backer, K., Menon, C., Desnoyers-James, I., \& Moussiegt, L. 2016. Reshoring: Myth or reality? OECD Science, Technology and Industry Policy Papers, No. 27, OECD Publishing, Paris. https://doi.org/10.1787/5jm56frbm38s-en.

De Marchi, V., Di Maria, E., \& Gereffi, G. (Eds.) 2017. Local clusters in global value chains: Linking actors and territories through manufacturing and innovation. London: Routledge.

De Propris, L., \& Pegoraro, D. 2019. Technological disruptions and production location choices. In A. Chidlow, P. N. Ghauri, T. Buckley, E. C. Gardner, A. Qamar, \& E. Pickering (Eds.), The Changing Strategies of International Business (pp. 221-240) London: Springer.

Delis, A., Driffield, N., \& Temouri, Y. 2019. The global recession and the shift to re-shoring: Myth or reality? Journal of Business Research, 103: 632-643.

Department for transport. 2011. Growing Place Fund. Prospectus. https://assets.publishing.service.gov.uk/government/ uploads/system/uploads/attachment_data/file/7521/ 2024617.pdf. Accessed 05 June 2020.

Di Mauro, C., Fratocchi, L., Orzes, G., \& Sartor, M. 2018. Offshoring and backshoring: A multiple case study analysis. Journal of Purchasing and Supply Management, 24(2): 108134.

Donnelly, T., Begley, J., \& Collis, C. 2017. The West Midlands automotive industry: The road downhill. Business History, 59(1): 56-74.

Eichengreen, B. 2020. Why hasn't the impact of the trade war been greater? Journal of Policy Modeling, 42(4): 820-828.

Eisenhardt, K. M. 1989. Building theories from case study research. Academy of Management Review, 14(4): 532-550.

Eisenhardt, K. M., \& Graebner, M. E. 2007. Theory building from cases: Opportunities and challenges. Academy of Management Journal, 50(1): 25-32.

Ellram, L. M., Tate, W. L., \& Petersen, K. J. 2013. Offshoring and reshoring: An update on the manufacturing location decision. Journal of Supply Chain Management, 49(2): 14-22.

Eurofound, 2019. Reshoring in Europe: Overview 2015-2018. Luxembourg: Publications Office of the European Union.

Eurostat, 2018. NUTS - Nomenclature of Territorial Units for Statistics. Available at https://ec.europa.eu/eurostat/web/ nuts/background. Accessed 20 June 2020.

Fenton, A., \& Procter, C. T. 2019. Studying social media communities: Blending methods with netnography. SAGE 
Research Methods Cases. London: SAGE. http://usir.salford.ac. uk/id/eprint/47958.

Fernandez-Stark, K., \& Gereffi, G. 2019. Global value chain analysis: A primer. In S. Ponte, G. Gereffi, \& G. Raj-Reichert (Eds.), Handbook on global value chains (pp. 54-76) Cheltenham: Edward Elgar Publishing.

Finley, T. K. 2019. The democratization of artificial intelligence: One library's approach. Information Technology and Libraries, 38(1): 8-13.

Foerstl, K., Kirchoff, J. F., \& Bals, L. 2016. Reshoring and insourcing: Drivers and future research directions. International Journal of Physical Distribution \& Logistics Management, 6(5): 492-515.

Forte, E., \& Miotti, D. 2015) Offshoring and reshoring policies in Southern Italy strategies of development and growth. Rivista Economica del Mezzogiorno, 3-4: 693-720.

Fratocchi, L., Ancarani, A., Barbieri, P., Di Mauro, C., Nassimbeni, G., Sartor, M., et al. 2016. Motivations of manufacturing reshoring: An interpretative framework. International Journal of Physical Distribution \& Logistics Management, 46(2): 98-127.

Fratocchi, L., Di Mauro, C., Barbieri, P., Nassimbeni, G., \& Zanoni, A. 2014. When manufacturing moves back: Concepts and questions. Journal of Purchasing and Supply Management, 20(1): 54-59.

Fratocchi, L., \& Di Stefano, C. 2019. Do Industry 4.0 technologies matter when companies evaluate reshoring decisions? IEEE International Workshop on Metrology for Industry 4.0 and loT, Metrolnd 4.0 and loT 2019 - Proceedings, art. no. 8792897:376-381.

Gadde, L. E., \& Jonsson, P. 2019. Future changes in sourcing patterns: 2025 outlook for the Swedish textile industry. Journal of Purchasing and Supply Management, 25(3): 100526.

Gamble, A. 2018. Taking back control: The political implications of Brexit. Journal of European Public Policy, 25(8): 1215-1232.

Gereffi, G. 2011. Global value chains and international competition. The Antitrust Bulletin, 56(1): 37-56.

Gereffi, G. 2018. Global value chains and development: Redefining the contours of 21st century capitalism. Cambridge: Cambridge University Press.

Gereffi, G., \& Sturgeon, T. 2013. Global value chain-oriented industrial policy: The role of emerging economies. In D. K. Elms \& P. Low (Eds.), Global value chains in a changing world (pp. 329-340) Geneva: WTO Publications.

Ghauri, P., Grønhaug, K., \& Strange, R. 2020. Research methods in business studies. Cambridge: Cambridge University Press.

Gobo, G. 2004. Sampling, representativeness, and generalizability. In C. Seale, G. Gobo, J. F. Gubrium, \& D. Silverman (Eds.), Qualitative research practice (pp. 405-426). London: SAGE.

GOV.UK. 2014. World Economic Forum (Davos) 2014: speech by David Cameron. https://www.gov.uk/government/ speeches/world-economic-forum-davos-2014-speech-bydavid-cameron-2. Accessed 16 June 2020.

Grappi, S., Romani, S., \& Bagozzi, R. P. 2018. Reshoring from a demand-side perspective: Consumer reshoring sentiment and its market effects. Journal of World Business, 53(2): 194-208.

Gray, J. V., Esenduran, G., Rungtusanatham, M. J., \& Skowronski, K. 2017. Why in the world did they reshore? Examining small to medium-sized manufacturer decisions. Journal of Operations Management, 49: 37-51.

Grey, D. E. 2020. Digital research methods. Doing research in the business world: 567-598 (2nd ed.) London: SAGE.

Guillén, M. F., \& García-Canal, E. 2009. The American model of the multinational firm and the "new" multinationals from emerging economies. Academy of Management Perspectives, 23(2): 23-35.

Gylling, M., Heikkilä, J., Jussila, K., \& Saarinen, M. 2015. Making decisions on offshore outsourcing and backshoring: A case study in the bicycle industry. International Journal of Production Economics, 162: 92-100.
Hamnett, C. 2018. A world turned upside down: The rise of china and the relative economic decline of the west. Area Development and Policy, 3(2): 223-240.

Hillebrand, B., Kok, R. A., \& Biemans, W. G. 2001. Theorytesting using case studies: A comment on Johnston, Leach, and Liu. Industrial Marketing Management, 30(8): 651-657.

Holweg, M., Davies, P., \& Wood, M. 2017. Growing the automotive supply chain: Local vehicle content analysis. Available at https://www.automotivecouncil.co.uk/wpcontent/uploads/sites/13/2017/06/Automotive-Council-UKlocal-sourcing-content-research-2017-Final-1.pdf. Accessed 15 June 2020

Humphrey, J., \& Schmitz, H. 2002. Developing country firms in the world economy: Governance and upgrading in global value chains. Heft $61 / 2002$.

lammarino, S., \& McCann, P. 2013. Multinationals and economic geography: Location, technology and innovation. Cheltenham: Edward Elgar Publishing.

Jick, T. D. 1983. Mixing qualitative and quantitative methods: Triangulation in action. In J. Van Maanen (Ed.), Qualitative methods. Beverly Hills: Sage.

Judge, W., \& Douglas, T. 2009. Organizational change capacity: The systematic development of a scale. Journal of Organizational Change Management, 22(6): 635-649.

Kandil, N., Battaïa, O., \& Hammami, R. 2020. Globalisation vs. Slowbalisation: A literature review of analytical models for sourcing decisions in supply chain management. Annual Reviews in Control, 49: 277-287.

Keller, F., \& Zoller-Rydzek, B. 2019. European Nearshoring Index-Is Eastern Europe Attractive for Swiss IT Firms? Central European Business Review, 8(3): 35.

Ketokivi, M., Turkulainen, V., Seppälä, T., Rouvinen, P., \& AliYrkkö, J. 2017. Why locate manufacturing in a high-cost country? A case study of 35 production location decisions. Journal of Operations Management, 49: 20-30.

Kiel, D., Müller, J. M., Arnold, C. and Voigt, K. I. 2017. Sustainable industrial value creation: Benefits and challenges of industry 4.0. International Journal of Innovation Management, 21(08): 1-34.

Kinkel, S. 2014. Future and impact of backshoring-Some conclusions from 15 years of research on German practices. Journal of Purchasing and Supply Management, 20(1): 63-65.

Kinkel, S., \& Maloca, S. 2009. Drivers and antecedents of manufacturing offshoring and backshoring-A German perspective. Journal of Purchasing and Supply Management, 15(3): 154-165.

Lampón, J. F., \& González-Benito, J. 2019. Backshoring and improved key manufacturing resources in firms' home location. International Journal of Production Research. https://doi. org/10.1080/00207543.2019.1676479.

Lavissière, A., Mandják, T., \& Fedi, L. 2016. The key role of infrastructure in backshoring operations: The case of free zones. Supply Chain Forum: An International Journal, 17(3): 143-155.

Lieb, R. C., \& Lieb, K. J. 2016. 3PL CEO perspectives on the current status and future prospects of the third-party logistics Industry in North America: The 2014 Survey. Transportation lournal, 55(1): 78-92.

Manufacturing Advisory Service. 2014. https://webarchive. nationalarchives.gov.uk/20140320153140/http://www.mas. bis.gov.uk/. Accessed 14 July 2019.

Markusen, J. R., \& Venables, A. J. 2000. The theory of endowment, intra-industry and multi-national trade. Journal of International Economics, 52(2): 209-234.

McKinsey \& Company. 2015. Manufacturing's next act. http:// www.timereaction.com/papers/manufacturing_next_act.pdf. Accessed 24 May 2020.

McKinsey \& Company. 2019. Globalization in transition: The future of trade and value chains. Available at: https://www. 
mckinsey.com/ /media/McKinsey/Featured\%20Insights/ Innovation/Globalization\%20in\%20transition\%20The\% 20future\%20of\%20trade\%20and\%20value\%20chains/MGIGlobalization\%20in\%20transition-The-future-of-trade-andvalue-chains-Full-report.ashx. Accessed 10 June 2020.

Miles, M., \& Huberman, A. 1984. Qualitative data analysis: A source book of new methods. Beverly Hills: Sage Publications.

Miles, M., \& Huberman, A. 1994. Qualitative data analysis: An expanded source book. Thousand Oak: Sage Publications.

Moradlou, H., Backhouse, C., \& Ranganathan, R. 2017. Responsiveness, the primary reason behind re-shoring manufacturing activities to the UK. International Journal of Physical Distribution \& Logistics Management, 47(2/3): 222-236.

Moretto, A., Patrucco, A. S., \& Harland, C. M. 2019. The dynamics of reshoring decisions and the role of purchasing. International Journal of Production Research. https://doi.org/10. 1080/00207543.2019.1661534.

Mucchielli, J. L., \& Puech, F. 2004. Globalization, agglomeration and FDI location: The case of French firms in Europe. In J. L. Mucchielli \& T. Mayer (Eds.), Multinational firms' location and the new economic geography (pp. 35-58). Cheltenham: Edward Elgar Publishing.

Mudambi, R. 2018. Knowledge-intensive intangibles, spatial transaction costs, and the rise of populism. Journal of International Business Policy, 1(1): 44-52.

Mudambi, R., Li, L., Ma, X., Makino, S., Qian, G., \& Boschma, R. 2018. Zoom in, zoom out: Geographic scale and multinational activity. Journal of International Business, 49(8): 928-941.

Mudambi, R., \& Puck, J. 2016. A global value chain analysis of the 'regional strategy' perspective. Journal of Management Studies, 53(6): 1076-1093.

Neilson, J., Pritchard, B., \& Yeung, H. W. 2017. Changing dynamics of GPNs, institutional evolution and regional transformation in the contemporary global economy. In J. Neilson, B. Pritchard, \& H. W. Yeung (Eds.), Global Value Chains and Global Production Networks (pp. 141-145). Oxon: Routledge.

Nielsen, B. B., Welch, C., Chidlow, A., Miller, S., Aguzzoli, R., Gardner, E., et al. 2020. Fifty years of methodological trends in JIBS: Why future IB research needs more triangulation? Journal of International Business Studies, 51: 1478-1499.

Nujen, B. B., Halse, L. L., Damm, R., \& Gammelsæter, H. 2018. Managing reversed (global) outsourcing: The role of knowledge, technology and time. Journal of Manufacturing Technology Management, 29(4): 676-698.

Nujen, B. B., Mwesiumo, D. E., Solli-Sæther, H., Slyngstad, A. B., \& Halse, L. L. 2019. Backshoring readiness. Journal of Global Operations and Strategic Sourcing 12(1): 172-195.

OECD. 2017. OECD Business and Finance Outlook 2017. http:// www.oecd.org/daf/oecd-business-and-finance-outlook-20179789264274891-en.htm. Accessed 5 June 2020.

Pal, R., Harper, S., \& Vellesalu, A. 2018. Competitive manufacturing for reshoring textile and clothing supply chains to highcost environment. The International Journal of Logistics Management, 29(4): 1147-1170.

Parrilli, M. D. 2019. Clusters and internationalization: The role of lead firms' commitment and RIS proactivity in tackling the risk of internal fractures. European Planning Studies, 27(10): 20152033.

Piekkari, R., \& Welch, C. 2004. Qualitative research methods in international business: The state of the art. Handbook of qualitative research methods for international business. https:// doi.org/10.4337/9781781954331.00013.

Pietrobelli, C., \& Rabellotti, R. 2011. Global value chains meet innovation systems: Are there learning opportunities for developing countries? World Development, 39(7): 1261-1269.

Pietrobelli, C., \& Staritz, C. 2018. Upgrading, interactive learning, and innovation systems in value chain interventions. The European Journal of Development Research, 30(3): 557574.
Rasel, S., Abdulhak, I., Kalfadellis, P., \& Heyden, M. L. 2019. Coming home and (not) moving in? Examining reshoring firms' subnational location choices in the United States. Regional Studies, 54(5): 704-718.

Rehnberg, M., \& Ponte, S. 2018. From smiling to smirking? 3D printing, upgrading and the restructuring of global value chains. Global Networks, 18(1): 57-80.

Resmini, L. 2019. Foreign direct investments, global value chains and regional development. In R. Capello, P. Nijkamp, \& A. Mickiewicz (Eds.), Handbook of Regional Growth and Development Theories: 218-238 (2nd ed.). London: Edward Elgar Publishing.

Robinson, P. K., \& Hsieh, L. 2016. Reshoring: A strategic renewal of luxury clothing supply chains. Operations Management Research, 9(3-4): 89-101.

Ryan, G. W., \& Bernard, H. R. 2000. Data management and analysis methods. In N. Densin \& Y. Lincoln (Eds.), Handbook of Qualitative Research: 769-802 (2nd ed.). SAGE: Thousand Oaks.

Siggelkow, N. 2002. Evolution towards Fir. Administrative Science Quarterly, 47(1): 125-159.

Siggelkow, N. 2007. Persuasion with Case studies. Academy of Management Journal, 50(1): 20-24.

Sirilertsuwan, P., Hjelmgren, D., \& Ekwall, D. 2019. Exploring current enablers and barriers for sustainable proximity manufacturing. Journal of Fashion Marketing and Management: An International Journal, 23(4): 551-571.

Srai, J. S., \& Ané, C. 2016. Institutional and strategic operations perspectives on manufacturing reshoring. International Journal of Production Research, 54(23): 7193-7211.

Stentoft, J., Mikkelsen, O. S., \& Jensen, J. K. 2016. Flexicurity and relocation of manufacturing. Operations Management Research, 9(3-4): 133-144.

Strange, R. 2020. The 2020 Covid-19 pandemic and global value chains. Journal of Industrial and Business Economics, 47: 455-465.

Strange, R., \& Zucchella, A. 2017. Industry 4.0, global value chains and international business. Multinational Business Review, 25(3): 174-184.

Tate, W. L., \& Bals, L. 2017. Outsourcing/offshoring insights: Going beyond reshoring to rightshoring. International Journal of Physical Distribution \& Logistics Management, 47(2/3): 106-113.

Tate, W. L., Ellram, L. M., Schoenherr, T., \& Petersen, K. J. 2014. Global competitive conditions driving the manufacturing location decision. Business Horizons, 57(3): 381-390.

The Independent. 2014. Made in Britain: Vince Cable to offer more cash to firms 'reshoring' production. https://www. independent.co.uk/news/business/news/made-britain-vincecable-offer-more-cash-firms-reshoring-production-9164548. html. Accessed 10 Sept 2020.

The White House. 2012. President Obama's Blueprint to Support U.S. Manufacturing Jobs, Discourage Outsourcing, and Encourage Insourcing. https:/obamawhitehouse. archives.gov/the-press-office/2012/01/25/fact-sheetpresident-obama-s-blueprint-support-us-manufacturing-jobsdis. Accessed 15 May 2020.

The White House. 2015. White House Announces Additional Commitments to the American Business Act on Climate Pledge. https://obamawhitehouse.archives.gov/the-pressoffice/2015/11/30/white-house-announces-additionalcommitments-american-business-act. Accessed 15 May 2020.

UK Government. 2014. Reshore UK: New government support to encourage manufacturing production back to the UK. https://www.gov.uk/government/news/new-governmentsupport-to-encourage-manufacturing-production-back-tothe-uk. Accessed 01 June 2020.

UK Government. 2017. UK industrial strategy. A leading destination to invest and grow. https://www.gov.uk/ government/publications/uk-industrial-strategy-a-leadingdestination-to-invest-and-grow. Accessed 7 July 2019. 
UK Government. 2018. Industrial Strategy: Building a Britain fit for the future. https://assets.publishing.service.gov.uk/ government/uploads/system/uploads/attachment_data/file/ 664563/industrial-strategy-white-paper-web-ready-version. pdf. Accessed 21 June 2020.

UNCTAD. 2017. Word Investment Report 2017: Investment and the digital economy. https://unctad.org/en/pages/ PublicationWebflyer.aspx? publicationid $=1782$. Access 10 June 2020 .

UNCTAD. 2018. Trade and development report 2018: Power, platforms and the free trade delusion. https://doi.org/10. 18356/8a599f63-en. Accessed 25 July 2019.

UNCTAD. 2019. Word Investment Report 2019: Special Economic Zone. https://unctad.org/en/pages/ PublicationWebflyer.aspx?publicationid=2460. Accessed 20 June 2020.

UNCTAD. 2020. Word Investment Report 2020: International production beyond the pandemic. Power, platforms and the free trade delusion. https://unctad.org/en/pages/newsdetails. aspx? OriginalVersionID=2396. Accessed 18 June 2020.

Valli, V. 2018. The Economic Consequences of Donald Trump. In The American Economy from Roosevelt to Trump: 163-180. London: Palgrave Macmillan.

van Assche, A. 2018. From the editor: Steering a policy turn in international business-opportunities and challenges. Journal of International Business Policy, 1(3-4): 117-127.

van Assche, A., \& Lundan, S. 2020. From the editor: COVID-19 and international business policy. Journal of International Business Policy, 3(3): 287-301. van Bergeijk, P. A. G. 2018. On the brink of deglobalisation...again. Cambridge Journal of Regions, Economy and Society, 11(1): 59-72.

Vanchan, V., Mulhall, R., \& Bryson, J. 2018. Repatriation or reshoring of manufacturing to the US and UK: Dynamics and global production networks or from here to there and back again. Growth and Change, 49(1): 97-121.

Wan, L., Orzes, G., Sartor, M., \& Nassimbeni, G. 2019. Reshoring: Does home country matter? Journal of Purchasing and Supply Management, 25(4).

Welch, C., \& Piekkari, R. 2017. How should we (not) judge the 'quality' of qualitative research? A re-assessment of current evaluative criteria in International Business. Journal of World Business, 52(5): 714-725.

Welch, C., Piekkari, R., Plakoyiannaki, E., \& PaavilainenMäntymäki, E. 2011. Theorising from case studies: Towards a pluralist future for international business research. Journal of International Business Studies, 42(5): 740-762.

Wiesmann, B., Snoei, J. R., Hilletofth, P., \& Eriksson, D. 2017. Drivers and barriers to reshoring: a literature review on offshoring in reverse. European Business Review, 10: 85-103.

WMCA. 2019. West Midlands industrial strategy. https://www. wmca.org.uk/media/2478/west-midlands-industrial-strategy. pdf. Accessed 20 Aug 2019.

Yin, R. K. 2012. Applications of case study research. London: SAGE.

See Table 3 and Fig. 2.

\section{APPENDIX}

Table 3 The coding scheme.

\begin{tabular}{lll}
\hline Name (code) & Push factors & Pull factors \\
\hline Political factors & - Instable currency & - Regulatory approvals \\
& - Lack compliance (international standards) & - Tax incentives \\
& - Unstable regional government & - Corporate taxes \\
& - Ad hoc policy \\
& - Intellectual property (IP) rights \\
& - Supporting state economies \\
& - Less administration \\
& - European Union law \\
& - Stable currency \\
Technological & - Information Communication Technologies (ICT) \\
& competence \\
& - ICT infrastructure \\
& - Technological investment \\
& - Manufacturing automation \\
& - Digitalization of production \\
& - Amazon Effect (e.g., less air freight) \\
& - Daily delivery (time-to-market)
\end{tabular}


Table 3 (Continued)

\begin{tabular}{lll}
\hline Name (code) & Push factors & Pull factors \\
Local actors factors & - Lack of skilled workforce (host country) & - Political stability \\
& - IP risk protection & - General economic environment \\
- Change in supply chain network interactions & - Market potential of the region \\
- Loss of interaction with key customers & - Easy access to financial markets \\
- Low infrastructure quality & - Hard-working skilled workforce \\
- Lack of reliability of transportation & - Involvement of local community \\
- Language barrier & - Local supplier network \\
- Different time zone & - High infrastructure quality \\
- Long geographical distance & - Cluster effect \\
- Loss of tacit knowledge (home country) & - Better logistics facilities \\
- General risk of disruptive events & - Made in \\
& - High quality of life \\
& - Patriotism \\
& - Environmental law \\
& - Reputation \\
& - Raw material \\
& - Global supply chain (GSC) restructuration
\end{tabular}

Source: Authors.

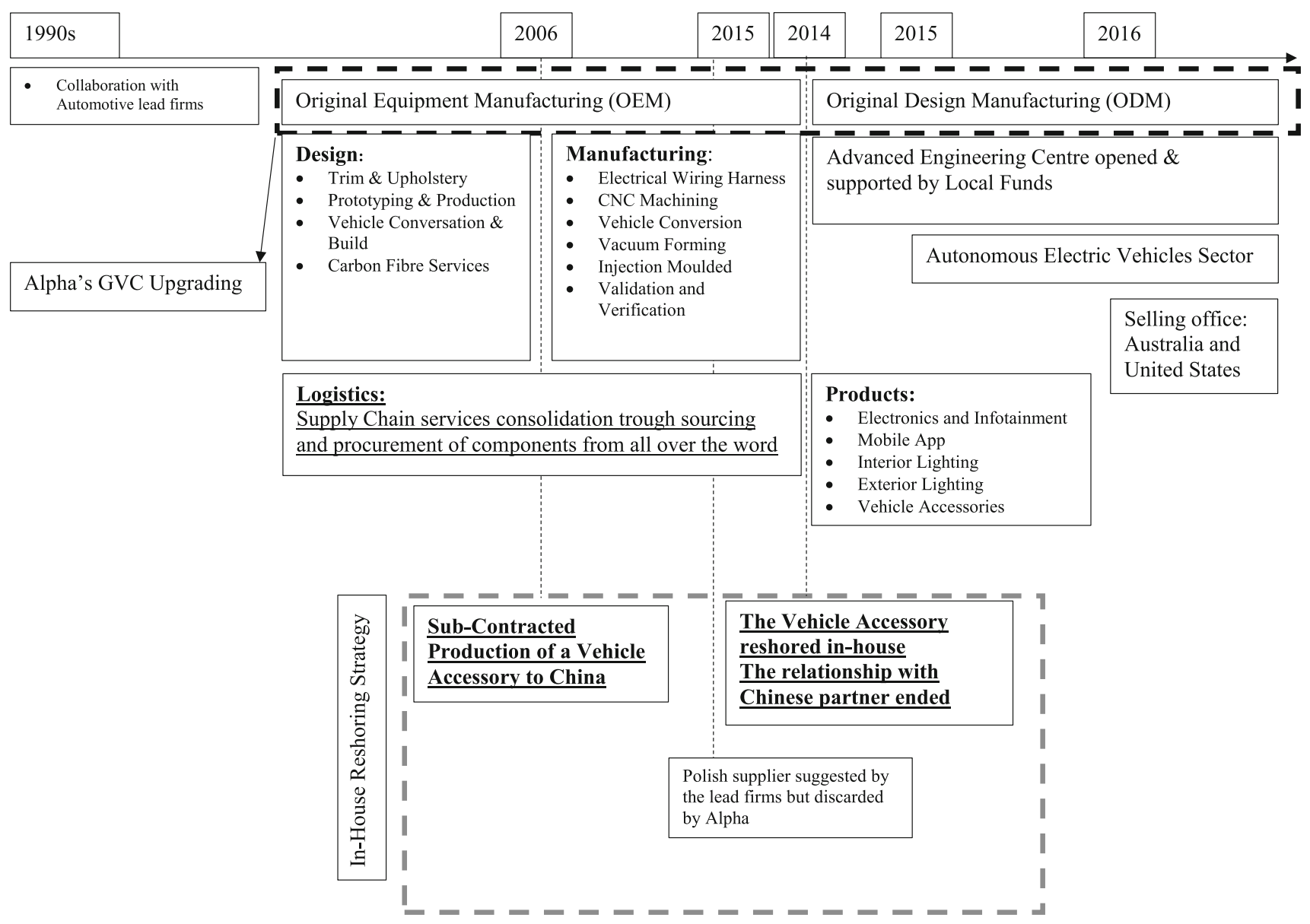

Fig. 2 Alpha's timeline. Source: Authors. 


\section{ABOUT THE AUTHORS}

Diletta Pegoraro is in her final year of her $\mathrm{PhD}$ at Birmingham Business School, University of Birmingham (UK). She holds a position as research assistant at the Department of Economics and Management, University of Trento. Her main research interests are in the field of international business, GVCs, and economic geography. She is an Officer at the AIB RM-SIG.

Lisa De Propris is Professor of Regional Economic Development in the Birmingham Business School. She has expertise in manufacturing, Industry 4.0, technological change, service clusters/districts, creative industries, regional economic development, industrial policy, and EU cohesion policy. She has completed a H2020 project on Industry 4.0 called MAKERS. She has extensively published on these themes in academic journals and books, as well as presented at international conferences and high-level meetings, including the EU Commission and OECD. Her recent publication is De Propris L. and Bailey D. (2020) Industry 4.0 and Regional Transformations, by Routledge (open access).

Agnieszka Chidlow is Professor of International Business at the University of Birmingham (UK). Her research interests lie in the areas of location choices of MNEs as well as methodological issues in international business with a specific focus on survey data. She is one of the co-founding members of the AIB RM-SIG. She is currently the AIB RM-SIG VicePresident for Responsible Research Methods, Working Board Member of the Responsible Research in Business and Management Network (RRBM), and Senior Editor for International Business Review.

Publisher's Note Springer Nature remains neutral with regard to jurisdictional claims in published maps and institutional affiliations.

Accepted by Roberta Rabellotti, Guest Editor, 25 March 2021. This article has been with the authors for five revisions. 